\title{
The Origins of the Broadbrow:
}

\section{Hugh Walpole and Russian Modernism in 1917}

\author{
Giannandrea Poesio \\ School of Media and Performance, University of Bedfordshire, Bedford and Luton, UK \\ Alexis Weedon \\ School of Culture and Communications, University of Bedfordshire, Bedford and Luton, UK
}

In his London Letter of May 1929 in the New York Herald Tribune, Hugh Walpole described the selection committee of the newly formed Book Society as "broadbrow". ${ }^{1}$ The term is an important one for the emerging mediums of the early twentieth century: radio, film, and their overlap with the older forms of theatre and the novel. This article focuses on the cultural construction of the term broadbrow and the artistic influence of Walpole's sojourn in Russia during the First World War on his novels which adopt symbolism and ekphrasis. $^{2}$ Walpole used the word "broadbrow" describe the intellectual combination of the playwright and actress Clemence Dane, ${ }^{3}$ academic Professor George Gordon, and authors Sylvia Lynd, J. B. Priestley, and himself. To these we may add the contributions of Edmund Blunden, who worked alongside Gordon and Priestley on the Book Society selection committee by 1932 . Together they had wide-ranging experience of the arts, and by invoking the term Walpole made a contradistinction with his imagined "highbrow" committee: Aldous Huxley, Raymond Mortimer, Edith Sitwell, Edwin Muir. ${ }^{4}$ The term came to be associated with Walpole and the Book Society and the discussion of taste in the 
1920s and 1930s.

The more commonly used "middlebrow" has received much critical attention. Joan Shelley Rubin's pioneering work on the emergence of the American middlebrow has led to valuable work on reevaluating women's reading in Britain by Alison Light and Nicola Humble. Janice Radway and Nicola Wilson have examined the work of the bookclubs in this commodification of the readable novel. Rosa M. Bracco's Merchants of Hope and Kate MacDonald's edited collection recapture the masculine middlebrow. This scholarship reclaims and questions the territory of the middle-list, the works of writers which sell steadily but are neither very popular fastsellers nor works which gain acclaim and endure. Journalists, intellectuals, and authors seeking higher literary rewards looked down on this market, as we see in Erica Brown and Mary Grover's edited collection which contextualises the "Battle of the Brows" between and after the wars. In the UK Alan Lane's famous sixpenny Penguins were drawn from these authors.

Allied to class distinction, but not restricted to it, the middlebrow stood for comfortable taste, middle price brackets in theatre and cinema seats, and book prices from $6 \mathrm{~d}$ to $3 \mathrm{~s} 6 \mathrm{~d}$. Such audiences could be wooed across media boundaries as Eliot Stannard, the scriptwriter, aimed to do when he sought to "turn into picture-goers" these middlinglycultured book readers through his film adaptations. ${ }^{5}$ In film studies researchers have explored case studies of middlebrow adaptation as in Lawrence Napper's work on Priestley's Good Companions in British cinema and Keith Williams's work on the broadbrow and the big screen in his cross disciplinary book on H. G. Wells. ${ }^{6}$ This article connects with this scholarship and others by focusing on the less used term "broadbrow" and the neglected author Hugh Walpole. 
This article argues that the "battle of the brows" between lowbrow, highbrow, and middlebrow in periodical press in the 1920s has obscured the richer qualities of the term "broadbrow", whose meaning had deeper resonances in the nineteenth century and early years of the twentieth century. Walpole's Russian experience in the First World War was formative: his wide reading across all fiction and his eclectic and voracious consumption of Russian modernism and culture formed an attitude to the arts which was more inclusive and less class-ridden than that which prevailed in Britain. Walpole's and Wells's definition of the broadbrow embraced an aspiration to be open to all experiences and to all knowledge which engendered "a noble and broad view of life". This openness was important to those who were finding a place within the emerging mediums of radio and film and seeking to engage and enlighten audiences of every kind.

Walpole's distinguishing quality was his ability to engage with all the arts. He read fiction voraciously, attended the theatre weekly, saw plays and operas on repeated occasions, and collected pictures and sculpture for his homes in Cumbria and London. With this prolific appetite for the arts he was able to make recommendations to friends, publishers, and later on to the wider public through radio and the Book Society. The function of the Society, he wrote, was "to emphasize a work worthy of general attention which might otherwise be lost in the general confusion" of the publication of sixty books a week. Walpole understood that "the sale of one book does not ruin the prospects of another book, as the success of one opera-singing tenor often destroys the hopes of another tenor."7 (His comparison of the two arts came from personal experience as he had supported the early career of the Wagnerian tenor Melchoir.) This ability to communicate his enthusiasm for the arts made him a sought-after presenter and spokesman. With this came celebrity: he 
performed on lecture tours in the USA, on the radio for the $\mathrm{BBC}$, and on film introducing George Cukor's adaptation of David Copperfield (MGM, 1935).

Before the newspapers" "wars of the brows" narrowed its definition, the term "broadbrow" was itself broader and was applied to film and radio as well as books and reading. In the press the meaning moved from a physiological description of the head to imply the broad learning of the mind within. Newspapers cited "broadbrowed Verulum", referring to Sir Roger Bacon, the last true Renaissance man, who reputedly knew all that there was to know in the arts and sciences. So when journalists reported that Gladstone was broadbrow in his oratory, they were complimenting the statesman on the breadth of his scholarship. In the twentieth century a newspaper claimed that the typical novel hero has "successively been a hairy poet, a cavalry lieutenant uniform, a broadbrowed doctor". 8 The term broadbrow was applied from the 1900 s to 1920 s to denote a youthful, unclouded vision, something heroic. It was used alongside the attributes of being large-hearted, undefeated, radiant, uninitiated, innocent, consecrated. Sometimes associated with the canny and thoughtful, it indicated the person was a thinker or philosopher dedicated to his humanitarian ideals in the profession of doctor or statesman. The young were especially enjoined to maintain a broad outlook: Dr. W. W. Vaughan, former head master at Rugby School, in a speech at a school prize day urged the boys to be industrious as well as brilliant, to get a knowledge of values and discriminate between the trivial and the important. They must "not to be high-brow, and still less low-brow, but broad-brow, so that they might take a noble and broad view of life." 9 It was also applied to military commanders, but it was not defined by class: on the King's coronation the Queen sat "broad-browed and radiant", ${ }^{10}$ yet the label was also used for an idealised "young Napoleon", a Scottish cleric, and a socially rising MP. Nor was it limited to Britons. 
Authors described Turkish watchguards and Russian soldiers as broad-browed ${ }^{11}$ and in the report of the resignation of General Ivanov in 1916 he was described as a broad-browed man, heroically "undefeated on the pitched battlefield". ${ }^{12}$

Walpole's use of the term is imbued with this appreciation of the Russian character and culture and the earlier connotations of breadth of knowledge and openness to experience. He was the son of a senior Anglican clergyman and a great fan of Anthony Trollope, and his liberalism was implicit in his "broad church" attitude toward doctrine. This quintessentially English eclectic diffidence is evident in The King Who Would Be a King, H. G. Wells's film story, where he said that the role of the broadbrow is "neither to disdain the current thing nor accept it, but to learn by attempting the impossible and to be content with a partial success". ${ }^{13}$ Such a proposition was meaningful to Walpole, who knew his own writing fell short of the highest standard, yet he still labored to improve his work and sought to emulate the tradition of Walter Scott. Scott was not "proud or a highbrow. There was no art for art's sake affection about him: he kept his technical amusements for his prefaces." ${ }^{14}$ But he wrote about all classes and drew on folk tales. Walpole read Scott and novelists of his own generation for enjoyment and was a great assessor of books. His popularity and judgement was so valued that he was invited to Hollywood to work on adaptations of British novels for the screen in the 1930s.

By the 1920s, however, the term had become ensnared in a distinction between highbrow and lowbrow. ${ }^{15}$ The labels lowbrow, highbrow, middlebrow, broadbrow, and nobrow were freely applied as judgement on taste in music, art, drama, and (lower in status) the cinema. Poking fun at the deleterious effect of movie melodramas on the young, Punch satirized the "Broadbrow" in a series of ballads written by A. P. Herbert in $1927 .{ }^{16}$ But it was accepted, even embraced as a positive epithet in publishing circles. ${ }^{17}$ In 1944 J. B. 
Priestley used the term in his obituary note for publisher Charlie Seddon Evans, who was always "trying to make us understand a little Egyptology or relativity, and exchanging droll anecdotes about authors". He had "a profound interest in publishing as an important factor in popular education", and a "flair for fiction of what used to be called the 'broadbrow' kind, soundly but not subtly written novels with a wide appeal." ${ }^{18}$ Evans had published John Galsworthy's Forsyte Saga in one volume and encouraged Maurice Baring, Brett Young, and Priestley to write long novels in defiance of the fashion for short ones. This meaning and its association with club selections and their membership continued through to 1966, when Tony Barrett described the book major book clubs: "Readers Union (Dent), higher brow; the Reprint Society, trading as 'World Books' and now merged with Book Club Associates (Smith and Doubleday), broad brow; and the Book Club (Foyles), lower brow."19

H.G. Wells, whom Walpole had known since 1910 when he and Arnold Bennett called him Hughie, referred to these overly pinning terms and sought to steer the debate in a new direction in 1929: "In the hasty and violent disputes and asseverations that constitute the bulk of literary, dramatic and cinema criticism, certain unavoidable classifications are continually in evidence. There is a pretension in one direction to be high and fine, in another to be easy and hearty, and in another to be broad and fruitful." ${ }^{20}$ As a reader for the publisher Martin Secker, Walpole was doing precisely that: seeking good novels and upand-coming writers for the Plain Man, or as he later defined him, "the Man in the Street plus a little culture". ${ }^{21}$ Walpole was also was a literary critic, prone to hasty disputes, but generous with his affirmations and more substantial support of writers, established and new. He was a long-term friend and correspondent of Henry James and Virginia Woolf, an appreciative reader of Lawrence, Huxley, and Joyce. However, in Wells's terms he was 
"broad and fruitful": broad in his interests in a wide range of arts and entertainments, and in his networks of authors, painters, broadcasters, and actors; fruitful as a prolific novelist who on average wrote a book a year for three decades.

Significantly, Wells related the term "broadbrow" to other media. While the matinee melodrama might get Punch's ridicule, Wells saw the potential in film and argued that a movie on war and world peace required a breadth of vision and aspiration which would not be found in highbrow and lowbrow attitudes:

The common nomenclature in these matters is insufficient; High-brow and Low-brow need to be supplemented by Broad-brow..... A film which is to have for its subject the present drive towards World Peace is as likely to be abhorrent to the High-brow as to the Low. It has to give and sustain a view and a thesis; it has to reflect upon the political side of everyone; it has to show man making war, tortured and slain by war, threatened by war and perhaps and very uncertainly able to abolish war. The High-brow will call it a tract and the Low-brow a sermon, and they will blunder together towards the exit in a violent struggle to escape with these assertions intact. The High-brow has nothing to learn and the Low-brow will learn nothing; in effect they are the same thing. They are out of this attempt. After all, the High-brow is only the Low-brow plus pretentiousness. It is the same sort of brain stood up on end. The Broad-brow remains to struggle with his immense and exciting subject. ${ }^{22}$

It was the valiant optimism in Wells's definition which was closest to Walpole's lived experience, for he had struggled with the "immense and exciting subject" of war and peace in Russia from 1915 to 1917. The intensity of his time in the art scene in Moscow and Petrograd and the daily contrast with his training as an orderly for the Russian Red 
Cross prior to going to the Galician front is recorded in his writings. His personal relationships with the English colony there and (more significantly for him) with the Russians he met were formative, both personally and politically. Being self-aware he described himself as a "sentimentalist" who put feeling and emotion above all else as a source of knowledge, and an "optimist" who found the idealism of the Russian revolution attractive. The breadth of this experience formed the foundations of his attitude to cultural production, and set him on the road to his concept of the broadbrow.

According to Anthony Cross, Walpole's fascination with Russia had started in $1912,{ }^{23}$ while reading Dostoevsky's Brothers Karamazov. Yet British dance historian and publisher Cyril Beaumont stated that "a then young Mr Walpole, the known writer, was among the guests excitedly shaking hands with all the Russian artists" ${ }^{\prime 2}$ at a party thrown in 1911, during the first London season of Sergej Diaghilev's Ballets Russes. The encounter with leading figures of the now legendary company before he went to Russia was to prove particularly important for Walpole. It introduced him to that idea of often idealised Russianess that had intoxicated Western audiences since Diaghilev's first visit to Paris in 1909 and may have led him to go to Russia as a war correspondent. It also connected him with the excitement of the distinctively Diaghilevian "art for art's sake" canon that informed the Ballets Russes and attuned Walpole to be receptive to artistic expressions during his stay in Russia. ${ }^{25}$ It is also likely Walpole secured some useful connections and introductions on this first encounter which helped him with his later work.

Rupert Hart-Davies (his biographer) relates how, unfit for the draft, Walpole travelled to the Eastern front as a volunteer medical orderly in September 1914. He stopped in Petrograd before joining his detachment on a tour of duty near Lviv in the Ukraine in May 1915. In six months he returned to the UK to raise support for a British 
initiative to counteract German propaganda, and in 1916, he went back to found the AngloRussian Bureau in Petrograd. During this period he kept two journals, wrote two novels, and maintained his correspondence with publishers and literary friends at home. ${ }^{26}$ In the back pages of his five year journal he listed books he read and the plays and operas he attended (Tables 1-3). It is a detailed record of an eclectic reader and theatregoer. In his short entries and in his war diary he records conversations on the differences between the Russians and the English, observations on Symbolism and Modernism, as well as his daily activities, which on April 5 started with the horror of assisting at the operating table in the morning and ended with falling asleep in the theatre in the evening after a long day's work. He wrote an official report on the early months of 1917 about the revolution for the British government, which contains his eyewitness account of the demonstrations and the shots fired at him. ${ }^{27}$ Later he published fragments of autobiography describing some of his experiences, including his fleeting meeting with Lenin.

Always the bookman, Walpole kept up his connection with literary life in England while he was in Russia. He received novels from Martin Secker to read and evaluate. He was very excited when he received his post, returning from Petrograd to Moscow in March 1915 to find more than fifty letters waiting, including correspondence from Henry James. To his delight he had a "splendid" offer from Methuen and a "good one" from Hodder and Stoughton, as well as an offer to translate The Duchess into Swedish. He continued to recommend authors. naming "women Ethel Sidgwick, Viola Meynell - men - [D. H.] Lawrence, [Walter L.] George, [Frank] Swinnerton, [John D.] Beresford, [Gilbert] Cannan and - quite new - [Francis] Brett Young, Ivor Brown - Certainly now not [Compton] Mackenzie" on his top list on March 19, 1915. ${ }^{28}$ 
British diplomat, journalist, and author Robert Hamilton Bruce Lockhart showed Walpole around Petrograd. The "English colony" included Arthur Ransome, who Walpole observed had not been "the same since the Wilde trial" - his book Oscar Wilde: A Critical Study had been withdrawn after a libel suit by Alfred Douglas ${ }^{29}$ - though his mood gradually improved. ${ }^{30}$ Other journalists and authors gathered round when Walpole ran the Anglo-Russian Bureau, including Harold Williams, a fluent Russian speaker. With these English and Russian friends he visited to the Bolshoi Theatre and the Moscow Arts Theatre, funded and directed by the two fathers of modern theatre, Vladimir Nemirovich Danchenko and Konstantin Stanislavsky. Nevertheless Walpole was determined to avoid the expats as much as possible. At age 31 , he wanted to experience life intensely and to record his own impressions of the Russian character and the war.

In Moscow, the first of the two big cities he lived in, Walpole attended a variety of performances and entertainment venues. Bruce Lockhart remembered that "Occasionally I went with Walpole to the ballet and to the circus. It was with Walpole, too, that I first met Gorky - at Nikita Baleiff's 'Bat.' ... actors and actresses going there to sup... a kind of club for the Moscow art theatre". ${ }^{31}$ Nested in a basement near the Moscow Arts Theatre, The Bat had been the first cabaret to open in Moscow in 1908, the brainchild of various artists belonging to both the Ballets Russes and the Arts Theatre circle: Stanislavsky, Nemirovich Dancenko, Diaghilev's designer Léon Bakst, the opera singer Feodor Chaliapin, playwright and political theorist Maxim Gorky, composer Sergej Rachmaninov, and one of Stanislavsky's most faithful disciples, Nikita Baliev, who was to undertake the directorship of the culturally thriving venue. It was in its minute auditorium sixty seats that Walpole found himself exposed to often feisty and quintessentially Russian debates on art as well as to well-devised performances. These revues were clearly devised in line with the innovative 
spirit promoted by the Arts Theatre (MAT). A few dance and song numbers, often of moral-challenging nature, framed the staging of short works by Pushkin, Gogol, and Gorky among others. Despite being themeless, the performances combined humor, music, and sheer fun with sections that focussed, more or less overtly, on the work of the actor, the work of the composer, and the art of the designer in current Russian culture, by challenging or commenting satirically on the Moscow scene.

Table 1. Performances seen in Moscow 1914-1915 from Hugh Walpole’s diaries.

\begin{tabular}{|c|c|c|}
\hline Title & Theatre & Date \\
\hline Lac des Cygnes Moscow Ballet, Tchiakovsky & Opera house Moscow & Sept 1914 \\
\hline Fairy tale of the Czar Sultan, Rimsky Korsakov & Opera house Moscow & Sept 1914 \\
\hline Sleeping Beauty, Tchiakovsky & Opera house Moscow & Sept 1914 \\
\hline The Captains Daughter, César Cui & Private Opera, Moscow & Oct 1914 \\
\hline Four at large? & Korš & Oct 1914 \\
\hline Mazeppa, Tchaikovsky & Private Opera, Moscow & Oct 1914 \\
\hline Lakme, Delibes & Moscow & Oct 1914 \\
\hline Giselle, Ballet & Opera, Moscow & Oct 1914 \\
\hline For King, Home and Liberty, Andreyev & Dram Mus & Nov 1914 \\
\hline A Life for the Czar, Glinka & Moscow Opera & Nov 1914 \\
\hline The Magic Mirror, Petipa & Moscow Opera & Nov 1914 \\
\hline Misfortune of being too clever, Griboyedov & MAT & Nov 1914 \\
\hline Czar Fyodorovich & MAT & Nov 1914 \\
\hline In These Days & Korš & Nov 1914 \\
\hline Prince Igor, Borodin & Moscow Opera & Nov 1914 \\
\hline Three Sisters, Tchekov & MAT & Nov 1914 \\
\hline Little Bit of Fluff, Walter Ellis & Criterion & Nov 1914 \\
\hline Comedy, A Ostrovsky & MAT & Dec 1914 \\
\hline Death of Pazukhin, Saltykow-Schtschedrin & MAT & Dec 1914 \\
\hline Hunchback [Hansli le bossu] ballet & Moscow Opera & Dec 1914 \\
\hline The Importance of being Earnest, Wilde & Dram Theatre & Dec 1914 \\
\hline Tosca, Puccini & - & Dec 1914 \\
\hline Don Quixote, Massenet & Moscow & Jan 1915 \\
\hline Eugene Onegin, Tchiakovsky & - & Jan 1915 \\
\hline Gaudeamus, Leonid Andreyev & Korš & Jan 1915 \\
\hline Three Turgeniev Plays & MAT & Jan 1915 \\
\hline Days of our Life, Leonid Andreyev & Korš & Jan 1915 \\
\hline La locandiera & MAT & Jan 1915 \\
\hline Cherry Garden & MAT & Jan 1915 \\
\hline Three Sisters, Tchekov & MAT & Feb 1915 \\
\hline
\end{tabular}

Baliev, moreover, delivered satirical monologues now and then, acting as a sort of enlightened conférencier or MC. He also dabbled in choreography, subtly parodying the Ballets Russes with his soon-world-famous "living dolls" - which were to be plagiarised in 
Britain by the Charles B. Cochran revues only ten years later. As Bruce Lockhart recalled in 1933: "Today, his troupe is well-known in Paris, London and New York as ever it was in Russia, but to my mind the performances have lost much of the delicious intimacy of those early Moscow days, when there was no gulf between player and audience." 32

The few existing descriptions of The Bat indicate that the culturally thriving, freethinking, and even slightly bawdy venue was a sort of First World War equivalent of the Weimar era cabarets described by Christopher Isherwood in his Berlin Stories, which inspired the musical Cabaret. Not unlike the famous Kit Kat Klub, The Bat intoxicated its patrons with a powerful concoction of satire, sex, catchy ditties, and political subversion. The tension of idleness caused by the wait to be recalled to the battlefront, and expectation of the horrors to come gave rise to a particular fervor, drowning the grim everyday reality in multiple outbursts of laughter, turkey trot, and cancan.

It was at The Bat that Walpole met Mikhail Lykiardopoulos (the secretary of the Moscow Arts Theatre) and he and Lockhart met Gorky. Lykiardopoulos or Lyki, as he was called by those close to him, was well known in Russia both for his translations of innovative Western works and as the man who had facilitated the collaboration between Edward Gordon Craig and Konstantin Stanislavsky, the outcome of which was a controversial (and disastrous) staging of Hamlet.

Lyki was to become a close friend of Walpole and a precious mentor and guide in his quest for understanding and absorbing the essence of Russian culture. His loud frank manners, his forward thinking, and above all his boisterous laugh ${ }^{33}$ made him an unlikely companion for the awkward Walpole, yet they got on famously. In his novel The Secret City Walpole's hero describes the fun they had visiting the circus: "I adore a circus; and when I can find one with the right sawdust smell, the right clown, and the right enthusiasm, 
I am happy." He observed "beautiful women in jewellery and powder, and young officers, and fat merchants in priceless Shubas." ${ }^{34}$ While at the cinema he saw a different class: "Soldiers, sailors, peasants, women, and children crowded together upon the narrow benches", and because the "cinema was a little one and the prices small the films were faded and torn...the Opera and the Place de la Concorde and the Louvre and the Seine danced and wriggled and broke before our eyes." ${ }^{35}$ The different audiences gave him foresight into the plight of the Russians he was later to see close up on the streets of Petrograd. His friendship with Lyki blossomed, and on Christmas Day 1915 they found themselves eating at the railway station. Lyki chaffed Walpole for his enthusiasm for Conrad whom he was writing a book about, exclaiming that Jack London was a better writer - and both were third rate. Walpole rose to the bait, saying in dismay that Lyki was a hopeless critic, ${ }^{36}$ but reflected later in his diary that they had read - and enjoyed - both authors. This idea that they could enjoy both high- and low-brow authors stayed with him.

In spite of mingling with artists like Baliev and Lyki, Walpole did not become a total convert to the modernist creed his Russian fellows believed in so firmly ${ }^{37}$ Like Wells he negotiated between popular culture and the avant garde. The list of performances he left behind (Tables 1 and 3) indicate that he preferred maintaining an open mind, perfectly in line with the stereotypical Baedeker-armed Englishman abroad, wishing to sample all sorts of different cultural activities, as portrayed in E. M. Forster novels. Next to the records of his visits to the Moscow Arts Theatre there are also many records relating to the Korš Theatre, a venue famous for traditional and glitzy productions of foreign plays, intended for conservative audiences interested only in big stars in action (Table 1). In addition to the choreographically subversive Ballets Russes, he went to see old ballet classics such as the full-length Swan Lake (the first performance he saw in Moscow), Sleeping Beauty, Giselle, 
and others from the now long-forgotten repertoire of the Imperial Ballet, such as Petipa's The Magic Mirror, the old romantic The Little Humpback Horse, and La Fille Mal Gardée. Indicative of his later rejection of the discomfort of the highbrow novel, Walpole's lists highlight a lack of interest in the more radical advances of theatre making of the time. There is no mention of the Nezlobin Theatre in Moscow, artistic and overtly proletarianoriented, which drew on experimentation that went far beyond the thresholds of Stanislavskian realism. Likewise, there are no references to Alexander Tairov, a disciple of Vsevolod Meyerhold, whose productions Walpole admired at the Alexandrinsky Theatre in Petrograd. Ukrainian-born Tairov had worked with Konstantin Somov at the short-lived but culturally significant Free Theatre in Moscow (1913). In the following year he launched, in the same city, the Kamerny Theatre (Chamber Theatre) which soon embraced, in wartime Russia, a Cubist/Futurist creed.

It is possible that Walpole's friendship with champions of a more moderate modernism, Lyki and Somov, informed his choices, leading him to draw the line against influences that were too radical but pulling him towards Russian Symbolism. It is also possible that his choice was being formed by his preference for "sentimental" theatre, that is drama which touched his emotions, whether it be the moderate modernism mentioned above, or the sheer fun and pleasure of the circus which he so enjoyed in Moscow. His recorded appreciations of plays at home or in Russia frequently mention the emotion of specific dramatic scenes and actors' performances. In his novels he developed ekphrastic description to convey the emotional impact of his experience as if they were portrayed through film, on stage, or in paintings.

Much of the excitement, shock, and confusion of the art scene he encountered in Moscow and his reading is conveyed in a war novel written largely while he was on duty. 
He and his publisher toyed with many titles including "Death and his Hunters", 38 "1915", and "The Fight in the Forest" ${ }^{39}$ before deciding on The Dark Forest, a phrase taken from a Russian proverb: "The heart of man is a dark forest because of the wolves there are in it". The novel shows the influence of the symbolists on Walpole and in particular of his close friend Konstantin Somov. ${ }^{40}$

An inveterate reader, Walpole had "learnt the habit during my first visit to the war of always taking a book in my pocket". ${ }^{41}$ In the first quarter of 1915 he was reading Conrad and Flaubert, alongside Secker's new issues which he was giving judgement on - Viola Meynell's Columbine, Ivor Brown's Years of Plenty, Gilbert Cannan's Young Earnest, and Francis Brett Young’s symbolist novel The Dark Tower: “Good but disappointing everything is there but the vitality" (Table 2). ${ }^{42}$ In between he read Robert Browning's The Ring and the Book and Edith Wharton's House of Mirth. He finished writing his biography of Joseph Conrad on May 4, just a fortnight before he left for the front.

Table 2 New books read 1914-1915 from Hugh Walpole's diaries.

$\begin{array}{lllll}\text { Title } & \text { Author } & \text { Publisher } & \text { Date } & \\ \text { Old Mole } & \text { George Cannan } & \text { Secker } & \text { Jan } & 1914 \\ \text { Modern Lovers } & \text { Viola Meynell } & \text { Secker } & \text { Jan } & 1914 \\ \text { Chance } & \text { Joseph Conrad } & \text { Methuen } & \text { Jan } & 1914 \\ \text { The Making of an Englishman } & \text { Walter L. George } & \text { Constable } & \text { Feb } & 1914 \\ \text { Business of a Gentleman } & \text { Humphrey N. Dickinson } & \text { Heinemann } & \text { Feb } & 1914 \\ \text { When Ghost met Ghost } & \text { William De Morgan } & \text { Heinemann } & \text { Feb } & 1914 \\ \text { Deep Sea } & \text { Francis Brett Young } & \text { Secker } & \text { Feb } & 1914 \\ \text { On the Staircase } & \text { Frank Swinnerton } & \text { Methuen } & \text { Mar } & 1914 \\ \text { Those against the World } & \text { Sheila Kaye-Smith } & \text { Chapman Hall } & \text { Apr } & 1914 \\ \text { The House in Demetrius Road } & \text { John D. Beresford } & \text { Heinemann } & \text { Apr } & 1914 \\ \text { The World Set Free } & \text { Herbert G. Wells } & \text { Macmillan } & \text { May } & 1914 \\ \text { Heroines and Others } & \text { St John Welles Lucas } & \text { Blackwood } & \text { May } & 1914 \\ \text { Justice of the Peace } & \text { Frederick Niven } & \text { Nash } & \text { July } & 1914 \\ \text { The Price of Love } & \text { Arnold Bennett } & \text { Methuen } & \text { Oct } & 1914 \\ \text { The Pastor's Wife } & \text { Elizabeth Von Arnim } & \text { Smith Elder } & \text { Oct } & 1914 \\ \text { The Encounter } & \text { Anne D Sedgwick, } & \text { Arnold } & \text { Oct } & 1914 \\ \text { Three Sisters } & \text { May Sinclair } & \text { Hutchinson } & \text { Oct } & 1914\end{array}$




$\begin{array}{lllll}\text { The Wife of Isaac Harman } & \text { Herbert G. Wells } & \text { Macmillan } & \text { Oct } & 1914 \\ \text { The Demi Gods } & \text { James Stephens } & \text { Macmillan } & \text { Nov } & 1914 \\ \text { The Rainbow } & \text { David H. Lawrence } & \text { Methuen } & \text { Nov } & 1914 \\ \text { Young Earnest } & \text { George Cannan } & \text { Secker } & \text { Jan } & 1915 \\ \text { Columbine } & \text { Viola Meynell } & \text { Secker } & \text { Jan } & 1915 \\ \text { Days of Plenty } & \text { Ivor Brown } & \text { Secker } & \text { Feb } & 1915 \\ \text { The Dark Tower } & \text { Francis Brett Young } & \text { Secker } & \text { Feb } & 1915 \\ \text { Within the Tides } & \text { Joseph Conrad } & \text { Dent } & \text { Mar } & 1915 \\ \text { The Invisible Event } & \text { John D. Beresford } & \text { Sedgwick } & \text { Mar } & 1915 \\ \text { The Voyage Out } & \text { Virginia Woolf } & \text { Duckworth } & \text { May } & 1915 \\ \text { Unofficial } & \text { John G.B. Lynch } & \text { Secker } & \text { May } & 1915 \\ \text { The Firelands } & \text { John Galsworthy } & \text { Heinemann } & \text { July } & 1915 \\ \text { The house of the many mirrors } & \text { Violet Hunt } & \text { Paul } & \text { July } & 1915 \\ \text { Of Human Bondage } & \text { William S. Maugham } & \text { Heinemann } & \text { July } & 1915 \\ \text { The Research Magnificent } & \text { Herbert G. Wells } & \text { Macmillan } & \text { Sept } & 1915 \\ \text { Victory } & \text { Joseph Conrad } & \text { Methuen } & \text { Oct } & 1915 \\ \text { Davenport } & \text { Charles Marriott } & \text { Hutchinson } & \text { Oct } & 1915\end{array}$

Walpole's writing is weighted with Dostevskian motifs and symbolism which reflect the emotions, states of mind, and ideas of both individuals and the broader populace. However the narrative of The Dark Forest was drawn from Walpole's battlefield experience, which gives the story and the war scenes great immediacy. He described how he wrote it: "Standing beside some carts in the Galician lane, my knees trembling with terror, the wounded moving restlessly on their straw, the afternoon light like the green shadow of a dried up conservatory, I found a pencil and, steadying my shaking body against the cart, I wrote PART II. CHAPTER 1 ....." ${ }^{43}$ Like Francis Brett Young he writes in "snatched hours" as the "only escape a harassed mind and an ailing body found at that time". ${ }^{44}$ Similarly in his novel two men love one woman: the dark forest, like the dark tower, becomes a symbol of entrapment. In Walpole's novel disoriented soldiers returning from the battlefield emerge from the wood confused and shocked, many are as "lost" as the dead and decaying are in the woods. The entangled forest also symbolises the complex motivations of the fully drawn character Semyonov, a "broadbrowed doctor" hero whose 
heart is "deeply and darkly" Russian. The story is that of two Englishmen who volunteer for the Russian Red Cross. One, Durwood, is an observer, too lame to be drafted in to the army, the other is a younger man, Trenchard, who is in love with a Russian girl called Marie whom he had just met in Petrograd and who accompanies them as a nurse. Awkward and naive, he loses her to Semyonov. When Marie gets shot Trenchard seeks to put himself in danger and both he and Semyonov become victims of the war. The Walpole-like character, Durwood, is also ill and leaves his unit to recover his health, believing his friends dead. "Whether I come out of this alive or not out of this very uncertain" wrote the author to his agent, a truth too for his character. ${ }^{45}$ The last chapter he said "was the hardest thing I have ever had to do."46

Walpole's early ekphrastic imagery of cinematic hallucination is expressionistic of trauma. In the novel the unit commandeers Polish country houses and halls as makeshift hospitals, carrying out first-line medical care before shipping the soldiers back up the line away from the front. These triage locations became for Durward (the narrator) a site of distorted reality as events pass "like the shadowed film of a cinematograph". ${ }^{47}$ In one instance Durwood works in a theatre

that at that early hour in the morning seemed to our weary eyes so fantastic. As we peered into it it was a huge place, already filled with wounded and lighted only by candles, stuck here and there in bottles. I could see, dimly, the stage at the back of the room, and still hanging, tattered and restless in the draught, a forgotten backcloth of some old play. ... a market-place filled with soldiers and their lovers. ${ }^{48}$ It was, he surmised, Bizet's Carmen. 'In the uncertain candlelight with the wounded groaning and crying in front of it", the backdrop became "absurd". Only six months before he went on his tour of duty he had been at the Moscow opera and he returned to see the 
Bizet opera in Petrograd in October. The weirdness of this juxtaposition permeated his life as well as his fiction: to his literary agent, James Brand Pinker, he confessed he loved to hear the news and gossip of London but "my life is so bizarre and melodramatic that the Garrick and beefsteak clubs are incredibilities". Admitting that the proofs of his latest work had not got through to him, he described the incongruity of his situation in Galicia:

I am sitting on a school-desk writing this to you by filthy candle because in half-anhour the man goes who takes the letters. I am trying to explain to the old lady that nothing will happen to her things, although as a fact in another two hours this room will be full of wounded, blood, Iodine, bandages and curses. ${ }^{49}$

The war brought into sharp relief the focus he needed to attend to the practicalities of living and doing his work. Away from the front he was able to reconnect with his professional life and to assert to Pinker that he would return in January with the book, stating that wanted a $£ 300$ advance from Secker, as the novel was, he said, "vivid" with "first-hand impressions...the Russian and English contrasts too are all I believe quite new" ${ }^{50}$ He said it was the very best thing he had done.

It could be argued, uncharitably perhaps, that The Dark Forest was an attempt to get into the market first with war novels from the Eastern front. Certainly Walpole went out as a journalist - he wrote articles for the Saturday Review - seeking the experience of war and Russian culture. His book had sentiment and immediacy, and Henry James commended him for its direct and vivid portrayal. Walpole's journals show how he refused pessimism and embraced intensity of feeling as the only reality. Many of the descriptive passages in the book are so close to his own experience that the emotion carries the narrative. If reflection and analysis might have given him greater standing amongst novelists, he valued sentiment more highly. His book had to convey his connection with the Russian character 
and its traits, and how it withstood the duress of war. Walpole dedicated The Dark Forest to Konstintin Somov, his friend and his second mentor in Russia.

Walpole's listings of performances he attended and his diary belie the rather grim portrayal of wartime Petrograd painted by Western historical accounts. More European and liberal than Moscow, Petrograd had a thriving cabaret culture. ${ }^{51}$ Social gatherings, though not as glittering as they once were, still took place, and the well-established Russian salon tradition continued. It was at one of the many parties organised by the French ambassador, Maurice Paléologue, that Walpole met the ballerina Tamara Karsavina. "I felt at once a very real sympathy for him," she recalled. "He was interested in Russian life and character, not as a study of the exotic and freakish, but from a genuine love and understanding of my country." $" 52$

Somov's guidance must have crowned Walpole's appreciation of Russia's new artistic trends. In Petrograd Vesevolod Meyerhold had taken, amidst the horror of his fellow reformers and the horror of the traditionalists, the artistic directorship of the Alexandrinksy Theatre - still the ultimate fortress and temple of Russian drama (Table 3). His radical approach to staging plays, which overtook and subverted Stanislavsky's modernism, must have had a great impact on Walpole, given that there are numerous records of his attending performances directed by Meyerhold.

Table 3. Performances in Petrograd and London 1915 from Hugh Walpole's diaries

Title

Eugene Onegin, Pyotr Ilyich Tchiakovsky

Yolka, Vladimir Ivanivich Rebikov

Dame de Pique (Queen of Spades)

Green Ring, Hippius, Zinaida Nicolayevna

Barber of Seville, Gioachino Rossini
Theatre

Conservatoria, Petrograd

Mariinsky, Petrograd

Mus. Dram. Petrograd

Alexandrinsky, Petrograd

Mariinsky, Petrograd
Month

Feb

Feb

Feb

Mar

Apr 
Ballet: Cleopatra, Armide

The Sisters

The Constant Prince, Pedro Calderon

La Fille Mal Gardee

Amazon, Arthur Pinero

Marriage of Belugin, A Ostrovsky \& N.Solovyov

Boris Godunov, Modest Mussorgsky

The Poor Heir, Alexander Ostrovsky

The Days of Our Life, Leonid Andreyev

Carmen, George Bizet

Fanny's First Play, George B. Shaw

Pygmalion, George B. Shaw

Big Drum, Arthur Pinero

Man Who Stayed At Home, Cecil M Hepworth

The Only Girl, Victor Herbert

Who Is He? Horace Annesley Vachell

The Ware Case, George Pleydell

$\begin{array}{ll}\text { Mariinsky, Petrograd } & \text { Apr } \\ \text { Alexandrinsky, Petrograd } & \text { Apr } \\ \text { Alexandrinsky, Petrograd } & \text { May } \\ \text { - } & \text { May } \\ \text { Duke of Yorks. London } & \text { June } \\ \text { Alexandrinsky, Petrograd } & \text { Sept } \\ \text { Mus. Dram. Petrograd } & \text { Sept } \\ \text { Alexandrinsky, Petrograd } & \text { Sept } \\ \text { - } & \text { Oct } \\ \text { Mus. Dram. Petrograd } & \text { Oct } \\ \text { - } & \text { Oct } \\ \text { Alexandrinsky, Petrograd } & \text { Oct } \\ \text { St James Alexander, London } & \text { Oct } \\ \text { Royalty, London } & \text { Nov } \\ \text { Apollo, London } & \text { Dec } \\ \text { Haymarket, London } & \text { Dec } \\ \text { Wyndhams, London } & \text { Dec }\end{array}$

Ballet, Walpole's new passion, only features twice in the list for 1915. One performance was Fille Mal Gardée danced by Karsavina and Mikhail Fokine, the choreographer who, thanks to his involvement with the Ballets Russes, had contributed so much to modern ballet. But the First World War had almost disbanded the Ballets Russes. Walpole also attended at the Mariinsky Theatre a double bill of Fokine's Pavillon d'Armide and Cleopatra, which had caused so much furore when presented by Diaghilev as part of his 1909 Saison Russe. Walpole was unimpressed: "it was not very good Fokine not being a patch on Nijinsky. The colours of 'Cleopatra' poor and the interval prodigious." 53

In wartime, the once influential and overactive Imperial Russian Ballet had indeed slowed down, especially since the first dancers' strike recorded in history had shattered its well-ordered ranks. It was against this background that in 1917 Vsevolod Meyerhold's long anticipated staging of Lermontov's play The Masquerade was performed. Walpole reported 
about it in his official memorandum of the early days of the Russian revolution, and it became part of his second Russian novel, The Secret City.

The Secret City describes Walpole's experience running the British office of propaganda in Petrograd and the lead up to the revolution. His novel must be read against his mission to defend against German propaganda of Cossack atrocities and demonstrate the good behavior of the Russian military. German troop movements to the Eastern front were forcing a Russian retreat in Poland with heavy casualties. So Walpole was sent back from Britain to Russia with a remit to establish an Anglo-Russian Bureau. He recruited Arthur Ransome and Harold Williams, who fed the Russian press pro-allied stories, and invited Moscow journalists to the UK to view British War efforts. He also set up a small office in Moscow with Bruce, who had good relations with Moscow's cultural life. Lockhart gave banquets, wrote stories for Russian trench newspapers, and took round propaganda films to the Russian troops. ${ }^{54}$

Rupert Hart-Davis said the Anglo-Russian bureau was ineffective, ${ }^{55}$ and Walpole's character in The Secret City bitterly complains that if they "had plastered the whole vast country from Archangel to Vladivostock with pamphlets, orators, and photographs it would not have altered, in the slightest degree, after events." 56 But Keith Neilson suggests the inclusion of intelligence within the propaganda office was a success. ${ }^{57}$ In fact Walpole's organization of an outfit which accommodated his propaganda efforts, alongside British intelligence gathering and the work of the embassy, mastered a difficult combination of government departments servicing the requirements of Britain's War Propaganda Bureau, the War Office, and the Foreign office. This success led Walpole on his return to became part of the Ministry of Information, a much sought-after position for writers in both world wars. 
The Secret City continues the story from The Dark Forest after a gap in time. It is a vivid description of life in Petrograd, its river, roads and canals providing a background for the drama of Russian families and bread queues, and the forces competing for power from the police to the (well-behaved) Cossack soldiers. Walpole's symbolism takes the frozen river Neva as the personification of the seething spirit of the Russian people, referring to Alexandre Benois's illustration of Pushkin's poem. ${ }^{58}$ The story comes to a climax as the people and revolutionary soldiers take to the streets. Walpole's ekphrastic descriptions frame the soldiers and citizens in compositions reminiscent of historic paintings of revolution (such as those by Delacroix, David, Duplessis-Bertaux, and Trimbull). In The Secret City he describes the revolutionaries with light and silhouette, color and a sound track:

Some one had lighted a large bonfire in the middle of the street and the flames tossed higher and higher into the air, bringing down the stars in flights of gold, flinging up the snow until it seemed to radiate in lines and circles of white light high over the very roofs of the houses. In front of the fire a soldier, mounted on a horse, addressed a small crowd of women and boys. On the end of his rifle was a ragged red cloth.

I could not see his face. I saw his arms wave, and the fire behind him exaggerated his figure and then dropped it into a stragg11ling silhouette against the snow. The street seemed deserted except for this group, although now I could hear distant shouting on every side of me, and the monotonous clap-clap-clap-clap of a machine-gun. 
In the novel the very ordinariness of expat life is contrasted with the stirrings of the revolution outside: Walpole describes the office in The Secret City like a set as it was "a very nice airy place, clean and smart, with coloured advertisements by Shepperson and others on the walls, pictures of Hampstead and St. Albans and Kew Gardens that looked strangely satisfactory and homely to me, and rather touching and innocent". ${ }^{59}$ After his day job, Walpole went to entertainments often with Somov, watching the wrestling and bareback riding. These visits connected him with Russian mass entertainment and contrasted to his trips with his other friends to witness a minority avant-garde culture. For Walpole at this time the two collided and his observations were drawn into his novels. Durwood for example sees a vaudeville show of acts by the poor and dispossessed seeking to earn a living. Yet he also saw that these entertainments were momentary refuges from the daily bread queues.

For Walpole's hero, the theatre reenacts war trauma. Meyerhold's lavish staging of Lermontov's Masquarade, depicting aristocratic privilege in an Othello-like plot set in Petrograd after the failed Decembrist revolt of 1825, jarred outrageously with the real lifeand-death struggles for food in the cities and ammunition in the battlefield. Walpole's horror is captured in this book, where it becomes a symbol, a labored trope: the theatre of war, the operating theatre, and the staged performance are linked in his mind. His ekphrastic description is a cinematic dream sequence:

As I watched I remember that I forgot the bad acting (the hero was quite atrocious), forgot the lapses of taste in the colour and arrangement of the play, forgot the artifices and elaborate originalities and false sincerities; there were, I have no doubt, many things in it all that were bad and meretricious - I was dreaming. I saw, against my will and outside my own agency, mingled with the gold 
screens, the purple curtains, the fantasies and extravagances of the costumes, the sudden flashes of unexpected colour through light or dress or backcloth—pictures from those Galician days that had been, until Semyonov's return, as I fancied, forgotten.

A crowd of revellers ran down the stage, and a shimmering cloud of gold shot with red and purple was flung from one end of the hall to the other, and behind it, through it, between it, I saw the chill light of the early morning, and Nikitin and I sitting on the bench outside the stinking hut that we had used as an operating theatre, watching the first rays of the sun warm, the cold mountain's rim. I could hear voices, and the murmurs of the sleeping men and the groans of the wounded. The scene closed. There was space and light, and a gorgeous figure, stiff with the splendour of his robes, talked in a dark garden with his lady. Their voices murmured, a lute was played, some one sang, and through the thread of it all I saw that moment when, packed together on our cart, we hung for an instant on the top of the hill and looked back to a country that had suddenly crackled into flame. There was that terrific crash as of the smashing of a world of china, the fierce crackle of the machine-guns, and then the boom of the cannon from under our very feet... the garden was filled with revellers, laughing, dancing, singing, the air was filled again with the air of gold paint, the tenor's voice rose higher and higher, the golden screens closed - the act was ended. ${ }^{60}$

In his official report on the Russian revolution in March 1917, Walpole recalled how there had been no national effort (as there had been in France and Britain) to provide the army with shells, guns, and equipment. The fighting machine was "daily handicapped by the inefficiency of the War Administration". ${ }^{61}$ In addition, "All through an exceptionally 
severe winter people had to wait in queues daily for several hours to obtain a ration of bread that was quite insufficient," ${ }^{62}$ and by the beginning of March even this supply began to fail. However, on March 8 the topic of discussion amongst the Petrograd intelligentsia was the "gorgeous revival" of Masquerade.

A performance that had been ten years in the making and was of a richness and extravagance that went oddly in company with a distressed and impoverished Russia. The weather was fine, the sight of rows of peasant women patiently waiting outside bread shops was by now commonplace, and it was argued that as people had showed such exemplary patience under such exasperating conditions for so long they would probably continue to show it a little longer. ${ }^{63}$

The following day some the newspapers did not appear. Great hostility was shown to the police and there were clashes, but the Cossacks disbursed crowds who were otherwise laughing and joking, as people came out to wander the streets, curious to find out what was happening with "wide-open eyes as if they were watching some melodrama in one of their cinematographs". That evening "the theatres were open and the cinematographs were crowded." The burning of the secret police dossiers the following Monday was trigger for the revolution, as Walpole wrote "it was a signal to the whole of Russia, and even to the world beyond Russia, that the Russian people were again a free people, and whatever mistakes they might make in the future, they were at least acting for themselves, their own rights, their own liberties." ${ }^{64}$ Of that week March 8-16, 1917: “One comment only any observer of the affair is compelled to make. The reserve, restraint, and discipline shown by the Russian people during this week were far, far greater than their most optimistic supporter could have been encouraged to expect." 65 
Walpole left Russia that November. His sympathy with the Russian people made the extremes of modernism, of high art, irreconcilable for him. He desired to connect with the Russian character at a time when revolutionary ideas and abject hunger drove the nation to revolution. What Walpole took from his time in Russia was not the avant garde, not a desire to follow the highbrow, but an understanding and appreciation of the effect of entertainment within society, of its value to people in all walks of life. This laid the foundations of his attitude to cultural production.

From his Cornish cottage in Polperro in 1917, Walpole's belief that there would be a good outcome in Russia faded, but his sympathy and compassion never left him. Later Walpole saw Somov again on his way to New York for an exhibition of Russian revolutionary art, but their relationship dwindled, for Walpole was unwilling to promote the exhibition. He felt that the "terrific purple shadow of Dostoevski" hung over Russian writers and, with Chekhov, convinced the Western public that Russian writers dealt with "machinery, suicide, and abortion" in scenes "that take place invariably either in the pelting rain or in underground cellars". This was not the humor and camaraderie Walpole remembered, and he welcomed the Book Society's choice in May 1929 of Valentine Kataev's The Embezzlers, the "first funny novel about Russia to reach England since Gogol." 66

In Russia, Walpole did not leave the distinctions of taste and the "brows" behind, as through his correspondence he kept close to the debates at home. He listed the books and theatre shows he saw at the back of the diary, giving them a status he did not give to the movies, cabaret, circus, or wrestling matches he attended. Perhaps his experience as a homosexual man in an intolerant time, or his role as a propagandist amongst spies, made him peculiarly aware of what could be avowed and owned in cultural and personal terms 
and what needed to be disavowed and concealed. Yet when his Russian friends and his work in the hospital unit brought him close to the Russian people and their culture he connected to them with the freedom of a foreigner unfettered by restrictive perceptions of social distinctions he felt in Britain. As Karsavina noted, Walpole had an earnest desire to know Russia, and he was exposed to men in many conditions at the front and later in the social ferment of the revolution. It was an open-armed attitude to culture which lead him later to propose a wide range of fiction and nonfiction to the Book Society committee.

In essence Walpole's experiences in Russia taught him to renegotiate the avant garde and the unhelpful distinction between High and Low culture. It prepared him to embrace the possibilities of radio and film as ways of engaging and enlightening diverse audiences of every kind. It opened him to all experience as a means of learning. Driven by sentiment and emotion, he was able to enjoy both simple and sophisticated forms of entertainment. Humanist in his focus on character and action, Walpole's broadbrow prized storytelling culture above engagement in artistic discourse. This made the broadbrow author ideal for the emerging mediums of the early twentieth century.

Acknowledgements: Weedon's archival research in The Henry W. and Albert A. Berg Collection of English and American Literature, The New York Public Library, Astor, Lenox and Tilden Foundations in 2016 was funded by Research Institute for Media, Art and Performance, University of Bedfordshire, with grateful thanks to Dr Giannandrea Poesio Director of the Institute. Hugh Walpole was one of ten authors identified for the AHRC funded project 'Cross-media co-operation in Britain in 1920s and 1930s' (AR 112216) and Weedon's work here is a follow-on from this project. 
Dedicated to the memory of Dr Giannandrea Poesio, this work is testament to his scholarship in Russian ballet and the arts. The article was completed for publication by Alexis Weedon following the authors' collaboration on the research, writing and co-presentation of the paper at the Laughing and Coping: Entertainment in WW1 conference March 2016 and the Postgraduate symposium May 2016 University of Bedfordshire.

Giannandrea Poesio was Reader in Dance and the Director of the Research Institute for Media, Arts and Performance at the University of Bedfordshire. Dance critic and columnist for The Spectator, and author of To and by Enrico Cecchetti, he was a regular contributor to Dance Europe and Danza \& Danza. He worked as historical consultant for the Royal Ballet School, the Royal Opera House, the Paris Opera, the Conservatoire de Boulogne/Billancourt, La Scala Theatre in Milan, the Theatre Academy in Helsinki, the Mariinsky Ballet in St Petersburg and was a winner of the Positano Danza Award in 2008.

Alexis Weedon holds the UNESCO chair in New Media Forms of the Book at the University of Bedfordshire. She is author of Victorian Publishing: The Economics of Book Production for a Mass Market (2003), with V.L. Barnett, Elinor Glyn as Novelist, Moviemaker, Glamour Icon and Businesswoman, (2014) and has edited History of the Book in the West (5 vols 2010). Co-editor of the research journal Convergence: the international journal of research into new media technologies with Julia Knight. This current paper is a new development of her research on crossmedia co-operation in the 1920s and 1930s which received AHRC funding in 2005-8. 


\section{Notes}

${ }^{1}$ Hugh Walpole, “London Letter”, New York Herald Tribune, May 1929, cutting from scrapbook. Sir Hugh Walpole collection of papers. The Henry W. and Albert A. Berg Collection of English and American Literature, The New York Public Library, Astor, Lenox and Tilden Foundations.

${ }^{2}$ Its relevance across early forms of the media is developed in Alexis Weedon, The Origins of Transmedia Storytelling in the Early Twentieth Century (London: Palgrave Macmillan, forthcoming).

${ }^{3}$ Clemence Dane, Tradition and Hugh Walpole (London: Heinemann, 1930).

${ }^{4}$ Nicola Wilson, "Middlemen, Middlebrow, Broadbrow", in Dougal McNeill and Charles Ferrall, eds., Futility and Anarchy? British Literature in Transition 1920-1940 (Cambridge: Cambridge University Press, 2018).

${ }^{5}$ Quoted in Ian MacDonald, "Mr Gilfil's Love Story: The Well-Made Screenplay in 1920”, Journal of British Cinema and Television, 5.2 2008, p. 229.

${ }^{6}$ Joan Shelley Rubin, The Making of Middlebrow Culture (Chapel Hill, University of North Carolina Press, 1992); Alison Light, Forever England: Femininity, Literature, and Conservatism between the Wars (London: Routledge, 1991); Nicola Humble, The Feminine Middlebrow Novel, 1920s to 1950s: Class, Domesticity and Bohemianism (Oxford: Oxford University Press, 2001); Janice Radway, A Feeling for Book: The Book-of-theMonth Club, Literary Taste, and Middle-Class Desire (Chapel Hill: University of North Carolina Press, 1997); Erica Brown and Mary Grover, eds., Middlebrow Literary Cultures: The Battle of the Brows, 19201960 (New York : Palgrave Macmillan, 2012; Rosa M. Bracco, Merchants of Hope: British Middlebrow Writers and the First World War, $1919-1939$ (Providence: Berg, 1993); Kate Macdonald, ed., The Masculine Middlebrow, 1880-1950: What Mr. Miniver Read (Basingstoke : Palgrave Macmillan, 2011); Lawrence Napper, British Cinema and Middlebrow Culture in the Interwar Years (Exeter: University of Exeter Press, 2014); Keith Williams, H.G. Wells and the Movies (Liverpool: Liverpool University Press, 2007). 
${ }^{7}$ Hugh Walpole, “London Letter”, New York Herald Tribune, May 1929, cutting from scrapbook. Sir Hugh Walpole collection of papers. The Henry W. and Albert A. Berg Collection of English and American Literature, The New York Public Library, Astor, Lenox and Tilden Foundations.

${ }^{8}$ A syndicated filler for the news of the day column, quoted here from Nottingham Evening Post, 25 August 1910 .

${ }^{9}$ The Times, July 4, 1932, p. 14.

${ }^{10}$ A syndicated report on the Coronation, Chelmsford Chronicle, 23 June 1911.

11 The Scotsman, 16 May 1904.

${ }^{12}$ Hull Daily Mail, 5 April 1916.

${ }^{13}$ H.G. Wells, The King Who Would Be King: A Film Story. Kindle edition, 1929.

${ }^{14}$ Clemence Dane, Tradition and Hugh Walpole (London: William Heinemann, 1930), 34.

15 There is a correlation (0.74) between the use of highbrow and lowbrow and a stronger correlation between middlebrow and lowbrow (.84) in British newspapers between 1850 and 1940, but no correlation between broadbrow and any other "brows". British Newspaper Archive (accessed 22 December 2017)

16 “The Dreadful Ballad of a Talkie Ruined Home”, in A. P. Herbert, Ballads for Broadbrows (London: Ernest Benn, 1930), 48-50.

${ }^{17}$ Wilson, “Middlemen, Middlebrow, Broadbrow”.

${ }^{18}$ The Times, December 2, 1944, p. 7.

${ }^{19}$ The Times, November 25, 1996, p. 13.

${ }^{20}$ Wells, King Who Would Be King, Loc 135.

${ }^{21}$ Hugh Walpole, Essay on Reading (New York: Harper \& Brothers, 1926) 90.

${ }^{22}$ Wells, King Who Would Be King, Loc 135.

${ }^{23}$ Anthony Cross, “The Secret City: Hugh Walpole, Russia, and His Novel about Petrograd”, Journal of European Studies 35(3): 315-37.

${ }^{24}$ See C. Beaumont, "London and Diaghilev", typewritten transcript of an address delivered at the Rudolf Steiner House, London, on May 14, 1955. Gift of the late and former Cecchetti Society Chair Diana Barker to the author. 
${ }^{25}$ Sjeng Scheijen, Diaghilev: A Life (London: Profile Books, 2009), 144-46.

${ }^{26}$ This paper uses Walpole's diaries at the Harry Ransom Center, University of Texas.

${ }^{27}$ This is at Harry Ransom Center and also reprinted in Rupert Hart-Davis's biography.

${ }^{28}$ Walpole Diary March 19, 1915.

${ }^{29}$ Arthur Ransome, Oscar Wilde: A Critical Study (London: Martin Secker, 1912).

${ }^{30}$ Walpole Diary January 15, 1917.

${ }^{31}$ R. H. Bruce Lockhart, British Agent (New York: Putnam's, 1933), 103.

${ }^{32}$ Ibid.

${ }^{33}$ See Konstantin Stanislavsky, My Life in Art (London: Geoffrey Bles, 1924).

${ }^{34}$ Hugh Walpole, The Secret City (New York, George H. Doran, 1919) Project Gutenberg ebook epub 245.

${ }^{35}$ Ibid.

${ }^{36}$ Walpole Diary, January 7, 1915.

${ }^{37}$ Aaron J. Cohen, Imagining the Unimaginable: World War, Modern Art and the Politics of Public Culture in Russia (Lincoln: University of Nebraska Press, 2008).

${ }^{38}$ Walpole Diary, April 25, 1915.

${ }^{39}$ Hugh Walpole to Michael Secker, November 7, 1915, Sir Hugh Walpole collection of papers. The Henry W. and Albert A. Berg Collection of English and American Literature, The New York Public Library, Astor, Lenox and Tilden Foundations.

${ }^{40}$ Murray Frame, “Cultural Mobilization: Russian Theatre and the First World War, 1914-1917”, Slavonic and East European Review, 90.2 (April 2012): 288-322. Hubertus Jahn, Patriotic Culture in Russia During World War I (Ithaca: Cornell University Press, 1995).

${ }^{41}$ Hugh Walpole, The Dark Forest (New York: Grosset \& Dunlap, 1916), 241.

${ }^{42}$ Walpole Diary, January-April, 1915.

${ }^{43}$ Hugh Walpole, "The Crystal Box: Fragments of Autobiography”, Bookman, February 1923, p. 688.

${ }^{44}$ Francis Brett Young, The Dark Tower (London: Mayflower, 1971), 10. 
${ }^{45}$ Hugh Walpole to James Brand Pinker, July 1, 1915, Sir Hugh Walpole collection of papers. The Henry W. and Albert A. Berg Collection of English and American Literature, The New York Public Library, Astor, Lenox and Tilden Foundations.

${ }^{46}$ Walpole Diary, October 2, 1915.

${ }^{47}$ Walpole, Dark Forest, 97.

${ }^{48}$ Ibid., 165.

${ }^{49}$ Hugh Walpole to James Brand Pinker, July 1, 1915, Sir Hugh Walpole collection of papers. The Henry W. and Albert A. Berg Collection of English and American Literature, The New York Public Library, Astor, Lenox and Tilden Foundations.

${ }^{50}$ Hugh Walpole to James Brand Pinker, September 10, 1915, Sir Hugh Walpole collection of papers. The Henry W. and Albert A. Berg Collection of English and American Literature, The New York Public Library, Astor, Lenox and Tilden Foundations.

51 Tamara Karsavina, Theatre Street (London: Heinemann, 1930), 313.

52 Ibid., 318.

${ }^{53}$ Walpole Diary, April 11, 1915.

${ }^{54}$ Perhaps unsurprisingly, Bruce Lockhart's book A British Agent, with an introduction by Walpole, became a choice of both the Book Society in UK, and the Book of the Month Club in America.

${ }^{55}$ Rupert Hart-Davis, Hugh Walpole (London: Macmillan, 1952), 156-64.

${ }^{56}$ Walpole, Secret City.

${ }^{57}$ Keith Neilson, “'Joy Rides’?: British Intelligence and Propaganda in Russia, 1914-1917”, Historical Journal 24.4 (December 1981): 885-906.

${ }^{58}$ Walpole, Secret City, 391 'In Pushkin's poem you feel the devastating power of the beast, and in Benois' pictures you can see it licking its lips as it swallowed down pillars and bridges and streets and squares with poor little fragments of humanity clutching and crying and fruitlessly appealing." He is referring to Pushkin's "The Bronze Horseman, a Petersburg story" (1833) and Benois illustrations published in the avant garde journal Mir iskusstva in 1904, and a second series from 1916-23. Megan Swift, "The Petersburg Sublime: Alexander Benois and the Bronze Horseman Series (1903-22),” Germano-Slavica, 2009, 17: 3-24. 
${ }^{59}$ Walpole, Secret City, 374

${ }^{60}$ Ibid.

${ }^{61}$ Hart-Davis, Walpole, 451.

${ }^{62}$ Ibid., 452.

${ }^{63}$ Ibid., 453.

${ }^{64}$ Ibid., 460.

${ }^{65}$ Ibid.

${ }^{66}$ Hugh Walpole, “The First Soviet Humourist: The Book Society's Second Choice - a Genuinely Comic Novel from the U.S.S.R,” Graphic, May 25, 1929, 385. 